approach in carrying out aging studies. In: Samis HV, Capobianco S, eds. Aging and biological rhythms. New York: Plenum, 1978:57-96.

- George NJR, Barnard RJ, Blacklock NJ. Frequency volume charts revealing physiological abnormalities. In: Sundin T, Mattiasson A, eds. Proceedings of the eleventh annual meeting of the international continence society. Lund: Skogs Trelleborg, $1981: 67-8$.

10 Aschoff J, Wever R. Human circadian rhythms : a multi-oscillatory system. Fed Proc 1976;35:2326-32.

11 Spiegel MR. Theory and problems of statistics. New York: McGraw-Hill, $1961 ; 73$.

12 Kirkland JL. The effect of ageing on urinary circadian rhythms. Manchester : University of Manchester, 1982. MSc thesis.

13 Siegel M. Nonparametric statistics for the behavioural sciences. New York: McGraw-Hill, 1956:116-27.

${ }^{14}$ Dubois D, Dubois EF. A formula to estimate the approximate surface area if height and length are known. Arch Intern Med 1916;17:863-71.

15 Brocklehurst JC, Dillane JB, Griffiths L, et al. The prevalence and symptomatology of urinary infection in an aged population. Geront Clin 1968;10:242-53.

16 Sourander LB. Urinary tract infection in the aged. An epidemiological study. Annales Medicinae Internae Fenniae 1966;55, suppl 45:1-55.

17 Hobson $\mathrm{W}$, Pemberton J. The health of the elderly at home. London: Butterworths, $1955: 79-80$.

${ }^{18}$ McGhie A, Russell SM. The subjective assessment of normal sleep patterns. $\mathcal{f}$ Ment Sci 1962;108:642-54.
19 Webb WB, Swinberne H. An observational study of sleep of the aged. Percept Mot Skills 1971 ;32:895-8.

20 Judge TG, Caird FI, Leask RGS, MacLeod CC. Dietary intake and urinary excretion of potassium in the elderly. Age Ageing 1974;3:167-73.

${ }^{21}$ Lewis WH, Alving AS. Changes with age in the renal function of adult men. Am F Physiol 1938;123:500-15.

22 Rowe JW, Andres R, Tobin JD, Norri AH, Shock NW. Age-adjusted standards for creatinine clearance. Ann Intern Med 1976;84:567-9.

${ }^{23}$ Dontas AS, Marketos SG, Papanayiatou P. Mechanisms of renal tubular defects in old age. Postgrad Med F 1972;48:295-303.

${ }^{24}$ Richter CP. Biological clocks in medicine and biology. Springfield: Thomas, $1965: 21$.

25 Moore RY, Eichler VB. Loss of a circadian adrenal corticosterone rhythm following suprachiasmatic lesions in the rat. Brain Res 1972;42:201-6.

${ }^{26}$ Stephan FK, Zuker I. Rat drinking rhythms: central visual pathways and endocrine factors mediating responsiveness to environmental illumination. Physiol Behav 1972;8:315-26.

27 Pittendrigh CS, Daan S. Circadian oscillations in rodents: a systematic increase of their frequency with age. Science 1974;186:548-50.

28 Wever RA. The circadian system of man. New York: Springer-Verlag, $1979: 80-1$.

(Accepted 14 September 1983)

\title{
Intranasal treatment with luteinising hormone releasing hormone agonist in women with endometriosis
}

\author{
R W SHAW, H M FRAS ER, H BOYLE
}

\begin{abstract}
An agonist analogue of luteinising hormone releasing hormone (buserelin) was successfully used to treat women with endometriosis. A dose of $200 \mu \mathrm{g}$ administered intranasally thrice daily was found to be effective in five patients, in whom the endometriotic lesions resolved after six months' treatment. Failure occurred in a sixth patient, who received only $400 \mu$ g once daily. Anovulation was induced in all subjects together with suppression of menstruation after the first month of treatment. Symptoms of abdominal pain, dysmenorrhoea, and dyspareunia were relieved during treatment, and one previously infertile patient conceived within two months of stopping treatment.

No side effects were reported with this dosage, and the results suggest a new form of treatment for patients with endometriosis.
\end{abstract}

\section{Introduction}

Endometriosis presents many problems with regard to aetiology, diagnosis, treatment, and management. Medical management of endometriosis has undergone important evolution during the past four decades, from the initial approaches of high dose diethylstilboestrol treatment ${ }^{1}$ and progestin only and pseudopregnancy regimens ${ }^{2}$ to the more recent use of the antigonado-

Centre for Reproductive Biology, Edinburgh EH3 9EW

R W SHAW, MD, FRCS, senior lecturer, department of obstetrics and gynaecology

H M FRASER, PHD, research scientist, Medical Research Council reproductive biology unit

H BOYLE, HNC, chief technician, National Health Service reproductive endocrine laboratory

Correspondence to: Professor R W Shaw, Academic Department of Obstetrics and Gynaecology, Royal Free Hospital, London NW3 2QG. trophic agent danazol. ${ }^{3}{ }^{4}$ These treatments are often effective, but considerable numbers of patients experience side effects severe enough to cause treatment to be stopped.

During the past few years long term studies of the effects of chronic treatment with agonist analogues of luteinising hormone releasing hormone in women and primates have shown that the pituitary cells secreting gonadotrophin become insensitive to stimulation by endogenous luteinising hormone releasing hormone with resultant suppression of ovarian secretion of steroid and anovulation. ${ }^{5-8}$ We report the results of a six month trial of the effect of such treatment on six patients with endometriosis and describe their hormonal and symptomatic response to treatment.

\section{Patients and methods}

The six patients studied were recruited from the infertility and gynaecology clinics of one of us. Endometriosis was diagnosed at laparoscopy or laparotomy in all patients while they were undergoing investigation for infertility or abdominal or pelvic pain. The format of the study was explained to each patient, and after giving their informed consent they were entered into the trial, which had been approved by the hospital ethical committee.

The first complete menstrual cycle after diagnosis served as a control cycle, during which no treatment was given but early morning urine samples were collected three times a week. On the second day of their next menstrual period the patients started treatment with the luteinising hormone releasing hormone agonist buserelin (D-ser (but) ${ }^{6}$ desgly ${ }^{10}$-luteinising hormone releasing hormone ethylamide) (Hoechst Pharmaceuticals). This was administered intranasally with a spray giving a measured dose of $100 \mu \mathrm{g}$. One patients (case 1) received $400 \mu \mathrm{g}$ buserelin once daily; the five other patients received $200 \mu \mathrm{g}$ buserelin intranasally three times daily.

Treatment was continued for 26-28 weeks except in the patient taking the analogue once daily, in whom it was stopped after 13 weeks (see below). At the end of this period laparoscopy was performed to assess the response to treatment and an endometrial biopsy specimen was taken. Buserelin was then stopped, and the patients were monitored until their first menstrual period.

Throughout the study the patients collected early morning urine 
samples three times weekly, and these were analysed for ratios of oestrogen to creatinine and pregnanediol to creatinine concentrations, as previously described, ${ }^{9}$ to establish ovarian steroidogenic function. Patients were reviewed every four weeks to assess the development of other symptoms or side effects. Blood samples were screened at three months and at the end of treatment for the development of antibodies to the luteinising hormone releasing hormone agonist, as previously described. ${ }^{10}$

\section{Results}

The table summarises the relevant clinical details of the patients, the extent of endometriosis (using the classification suggested by Kistner et $\left.a l,{ }^{11}\right)$ and the response to treatment.

The first patient recruited to the trial received only $400 \mu \mathrm{g}$ buserelin once daily, which is the dose that was previously used to suppress ovulation in contraceptive trials with this agent. This patient continued to have episodes of abdominal pain, and the endometrioma appeared to increase in size. For this reason, after 13 weeks of treatment she underwent laparotomy. The size of her endometrioma had been such that any form of medical treatment was unlikely to succeed, but she had originally refused surgery.

In view of this failure with the first patient subsequent recruits were started on a larger dose of buserelin. During the first month of treatment with buserelin $200 \mu \mathrm{g}$ thrice daily three of the five patients experienced some vaginal bleeding between the first and fifth days, but it was not as heavy as normal menstruation. Thereafter, they remained amenorrhoeic while being treated, although one patient had occasional episodes of scant vaginal bleeding, with no set pattern, lasting one to two days.

Ovulation was suppressed in all six patients while they were taking the analogue, as indicated by the urinary pregnanediol concentrations, but the pattern of oestrogen secretion fell into two broad categories. Three patients showed a pattern of persistently suppressed oestrogen secretion with values in the range found in the early follicular phase. The other three patients showed a pattern of intermittent surges of oestrogen, though not to midcycle peak concentrations, which suggested waves of follicular development with failure to proceed to ovulation. No regular pattern was discernible, but any episodes of bleeding coincided with falls in oestrogen concentrations. The figure shows urinary steroid profiles in two patients, one from each category.

Laparoscopy at the end of treatment with the analogue showed an excellent response in five patients (cases 2-6) with scarring and resolution of all endometriotic areas. One patient (case 2) conceived within two months of stopping treatment.

The histology of the endometrial biopsy specimens obtained just before the end of analogue treatment corresponded well with the type of oestrogen secretory pattern observed during treatment. The three patients with suppressed flat patterns had proliferative atrophic, poorly developed endometriums, and those who had maintained higher oestrogen output had endometriums consistent with days 10-13 of a normal menstrual cycle. There was no evidence of cystic glandular hyper-

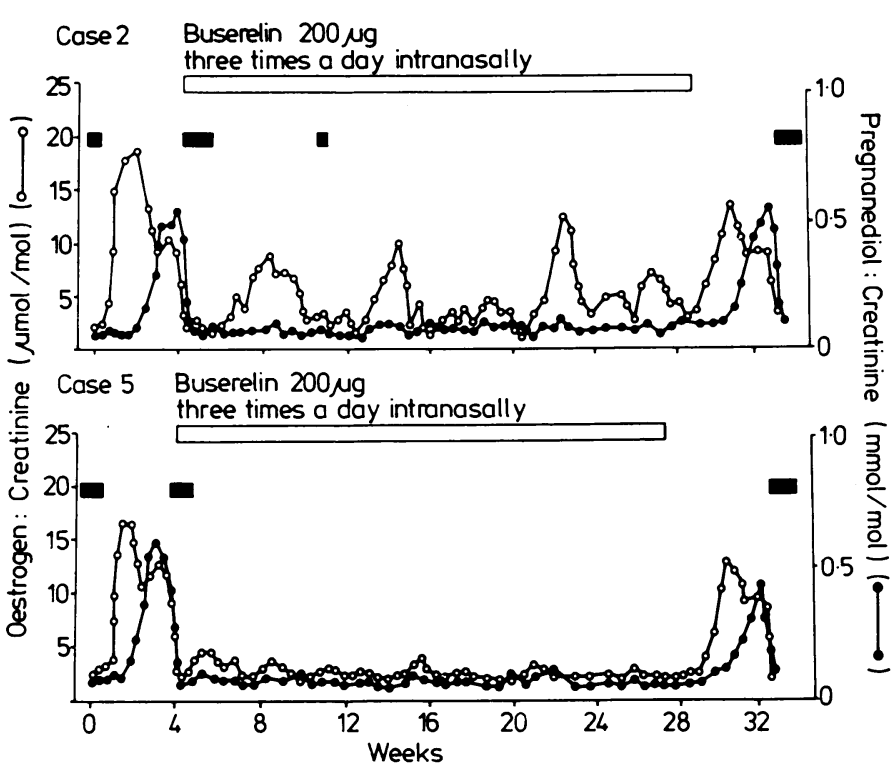

Pattern of urinary oestrogen and pregnanediol excretion in two patients receiving buserelin $200 \mu \mathrm{g}$ intranasally thrice daily for six months, showing the patterns of ovarian secretion of steroid observed. Shaded blocks indicate periods of bleeding.

Conversion: SI to traditional units-Creatinine: $1 \mathrm{~mol} \approx 113 \mathrm{~g}$. Oestrogen: $1 \mu \mathrm{mol} \approx 288 \mu \mathrm{g}$. Pregnanediol: $1 \mathrm{mmol} \approx 320 \mathrm{mg}$.

plasia or atypia developing. The histological assessments were all done by the same person.

Although one patient noted reduced vaginal secretion during treatment, this did not cause any coital problems, and the other patients did not develop any side effects or symptoms of oestrogen deficiency. No antibodies to buserelin were found in the blood samples analysed. The symptoms of pain and dyspareunia resolved completely during treatment.

The first spontaneous menstruation in the five patients who completed treatment began 18-27 days after analogue treatment was stopped. In three patients the ovulatory cycles were normal; the two others had shortened luteal phases with low excretion of pregnanediol.

\section{Discussion}

Our results establish that long term treatment with luteinising hormone releasing hormone agonist, leading to suppression of ovarian steroid production, can result in the resolution of endometriotic tissue in women. This confirms a recent study on the effects of a luteinising hormone releasing hormone agonist in monkeys with experimentally induced endometriosis, which was

Clinical details and duration and outcome of treatment in six women

\begin{tabular}{|c|c|c|c|c|c|c|c|}
\hline $\begin{array}{l}\text { Case } \\
\text { No }\end{array}$ & $\begin{array}{l}\text { Age } \\
\text { (years) }\end{array}$ & Symptoms at presentation & $\begin{array}{l}\text { Classification of } \\
\text { endometriosis } \\
\text { treated }\end{array}$ & $\begin{array}{l}\text { Dosage of } \\
\text { buserelin }\end{array}$ & Duration of treatment & History & $\begin{array}{l}\text { Follow up } \\
\text { laparoscopy }\end{array}$ \\
\hline 1 & 33 & Abdominal pain, dysmenorrhoea & IIA $_{2}$ & $\begin{array}{l}400 \mu \mathrm{g} \\
\text { once daily }\end{array}$ & $\begin{array}{l}19 \text { September- } \\
7 \text { December } 1981\end{array}$ & $\begin{array}{l}\text { Laparoscopy, April } 1981 \text {. } \\
\text { Endometrioma of left ovary } 7 \mathrm{~cm} \text {, } \\
\text { numerous other deposits } 2 \mathrm{~mm} \text {. } \\
\text { Started danazol, but stopped in } \\
\text { July } 1981 \text {. Pain persisted. } \\
\text { Laparotomy in December } 1981 . \\
\text { Hysterectomy and left } \\
\text { salpingo-oophorectomy }\end{array}$ & \\
\hline 2 & 22 & $\begin{array}{l}\text { Primary infertility for } 24 \text { months, } \\
\text { dyspareunia }\end{array}$ & IIA & $\begin{array}{l}200 \mu \mathrm{g} \\
\text { thrice daily }\end{array}$ & 2 January-7 July 1982 & $\begin{array}{l}\text { Laparotomy in November } 1981 \text {. } \\
\text { Right oophorectomy. } \\
\text { Endometrioma } 20 \mathrm{~cm} \text {; numerous } \\
\text { other deposits noted } 2-5 \mathrm{~mm}\end{array}$ & $\begin{array}{l}\text { All resolved. } \\
\text { Pregnant } \\
\text { September } 1982\end{array}$ \\
\hline 3 & 29 & $\begin{array}{l}\text { Primary infertility for } 36 \text { months, } \\
\text { abdominal pain }\end{array}$ & $11 \mathrm{~A}$ & $\begin{array}{l}200 \mu g \\
\text { thrice daily }\end{array}$ & $\begin{array}{l}17 \text { August } 1982- \\
22 \text { February } 1983\end{array}$ & $\begin{array}{l}\text { Laparoscopy in July } 1982 \text {. } \\
\text { Confirmed endometriosis; } \\
\text { numerous deposits } 5 \mathrm{~mm} \text { in } \\
\text { diameter on ovaries and cul de sac }\end{array}$ & $\begin{array}{l}\text { All resolved except } \\
\text { one lesion } 2 \mathrm{~mm} \\
\text { in diameter }\end{array}$ \\
\hline 4 & 27 & $\begin{array}{l}\text { Primary infertility for } 28 \text { months, } \\
\text { dysmenorrhoea }\end{array}$ & I & $\begin{array}{l}200 \mu \mathrm{g} \\
\text { thrice daily }\end{array}$ & $\begin{array}{l}13 \text { September } 1982- \\
29 \text { March } 1983\end{array}$ & $\begin{array}{l}\text { Laparoscopy in August 1982. } \\
\text { Numerous endometriotic lesions } \\
2 \mathrm{~mm} \text { within pelvis }\end{array}$ & All areas resolved \\
\hline 5 & 26 & Primary infertility for 48 months & IIA & $\begin{array}{l}200 \mu \mathrm{g} \\
\text { thrice daily }\end{array}$ & $\begin{array}{l}11 \text { November } 1982- \\
5 \text { May } 1983\end{array}$ & $\begin{array}{l}\text { Laparotomy in October } 1982 \text {. Left } \\
\text { ovarian endometrioma } 8 \mathrm{~cm} \\
\text { excised. Numerous other deposits } \\
\text { on bladder, cul de sac, right } \\
\text { ovary } 2-5 \mathrm{~mm}\end{array}$ & All areas resolved \\
\hline 6 & 23 & Primary infertility for 30 months & IIA & $\begin{array}{l}200 \mu \mathrm{g} \\
\text { thrice daily }\end{array}$ & $\begin{array}{l}9 \text { December } 1982- \\
5 \text { May } 1983\end{array}$ & $\begin{array}{l}\text { Laparoscopy in October } 1982 \text {. } \\
\text { Endometriotic deposits on ovaries } \\
\text { cul de sac, uterosacrals } 2-5 \mathrm{~mm}\end{array}$ & All areas resolved \\
\hline
\end{tabular}


effective in 12 out of 15 animals when given for three months, ${ }^{12}$ and extends previous preliminary results in women with endometriosis. ${ }^{13} 14$

The one patient who did not respond to the treatment had a particularly severe form of the disease and was treated with agonist only once daily. During the course of this and other studies it became apparent that more frequent administration of the agonist might be more effective in maintaining suppression of follicular oestradiol (J Brancroft, R W Shaw, H M Fraser, unpublished findings).

As reported in other studies on the effects of long term treatment with a luteinising hormone releasing hormone agonist for contraception ${ }^{6}{ }^{8}$ the return of ovulatory cycles after the end of treatment was not delayed. Indeed, one of the patients who had presented with infertility became pregnant two months after stopping treatment with the agonist.

Although no important side effects of the agonist were reported during the six month treatment regimen, longer term treatment may lead to a degree of oestrogen suppression that results in hot flushes developing in some women, as has been observed in patients receiving agonist treatment for the premenstrual tension syndrome (J Brancroft, $R$ W Shaw, H M Fraser, unpublished findings). It may well be necessary, however, to endeavour to achieve almost total suppression of ovarian function to allow endometriotic lesions to resolve and avoid the problem of prolonged unopposed oestrogen acting on the endometrium.

We thank Dr P Magill of Hoechst for supplying the luteinising hormone releasing hormone analogue and $\mathrm{Mr} \mathrm{L}$ MacKenzie for assessing the endometrial biopsy specimens.

\section{References}

1 Karnaky KJ. The use of stilbestrol for endometriosis-preliminary record. South Med F 1948;41:1109-11.
${ }^{2}$ Kistner RW. The use of progestins in the treatment of endometriosis. Am f Obstet Gynecol 1958;750:264-78.

${ }^{3}$ Friedlander RL. The treatment of endometriosis with danazol. $\mathcal{F}$ Reprod Med 1973;10:197-9.

${ }^{4}$ Laversen NH, Wilson KH, Birnbaum S. Danazol: an antigonadotropin agent in the treatment of pelvic endometriosis. Am $\mathcal{F}$ Obstet Gynecol 1975;123:742-7.

${ }^{5}$ Schmidt-Gollwitzer M, Hardt W, Schmidt-Gollwitzer K, et al. Influence of the LHRH analogue buserelin on cyclic ovarian function and on endometrium. A new approach to fertility control. Contraception 1981; 23:187-95.

${ }^{6}$ Bergquist C, Nillius SJ, Wide L. Intranasal LHRH agonist treatment for inhibition of ovulation in women: clinical aspects. Clin Endocrinol 1982;17:91-8.

' Vickery BH. Female contraceptive potential of "super" agonists of LHRH as assessed in intra-human primates: In: Zatuchni G, ed. $L H R H$ peptides as male and female contraceptives. Philadelphia: Lippincot, 1982 : 109-25.

${ }^{8}$ Fraser HM. Effect of treatment for one year with a luteinizing hormonereleasing hormone agonist on ovarian, thyroidal and adrenal function and menstruation in the stumptailed monkey (Macaca arctoides). Endocrinology 1983;112:245-53.

${ }^{9}$ Howie PW, McNeilley AS, Houston MJ, et al. Fertility after childbirth: infant feeding patterns, basal PRL levels and post partum ovulation. Clin Endocrinol 1982;17:315-22.

10 Fraser HM, Sandow J, Krauss B. Antibody production against an agonist analogue of luteinizing hormone-releasing hormone: evaluation of immunochemical and physiological consequences. Acta Endocrinol 1983;103:151-7.

${ }^{11}$ Kistner RW, Siegler AM, Behrman SJ. Suggested classification of endometriosis relationship to infertility. Fertil Steril 1977;28:1008-10.

12 Werlin LB, Hodgen GD. Gonadotropin-releasing hormone agonist suppresses ovulation, menses, and endometriosis in monkeys : an individualized intermittent regimen. F Clin Endocrinol Metab 1983;56:844-8.

13 Meldrum DR, Chang RJ, Lu J, et al. "Medical oophorectomy" using a long-acting GnRH agonist-a possible new approach to the treatment of endometriosis. C Flin Endocrinol Metab 1982;54:1081-3.

14 Lemay A, Quesnel G. Potential new treatment of endometriosis: reversible inhibition of pituitary ovarian function by chronic intranasal administration of a luteinizing hormone-releasing hormone (LHRH) agonist. Fertil Steril 1982;38:376-9.

(Accepted 14 September 1983)

\title{
Acne and anticonvulsants
}

\author{
R GREENWOOD，P B C FENWICK, W J CUNLIFFE
}

\begin{abstract}
The severity of acne and rate of excretion of sebum were assessed in 243 patients with epilepsy taking various anticonvulsants who were in hospital long term and in matched controls derived from a normal population of 2176 people. Neither the prevalence of acne nor the sebum excretion rate significantly increased in the patients compared with the controls or in patients taking phenytoin compared with those not.
\end{abstract}

It is concluded that anticonvulsant treatment does not cause acne.

\section{Introduction}

Phenytoin was first made available for the treatment of epilepsy in 1938. Since then, despite a lack of clinical and scientific evidence, it has been widely believed and taught that anticonvulsants, and in particular phenytoin, cause or aggravate acne. ${ }^{1}$ We report the results of a study of patients with epilepsy who were taking anticonvulsants and were in hospital long term. We set out to ascertain whether acne was more prevalent in patients with epilepsy than in the general population. Seborrhoea is cited as being one of the causative factors in acne, ${ }^{2}$ and we therefore measured the rate of excretion of sebum in a selected number of the patients. We also studied particularly those patients taking phenytoin as this is the drug most commonly linked with acne.

\section{Subjects and methods}

We studied 131 men (aged 16-70) and 111 women (aged 17-70). We graded the severity of their acne with a standardised technique with a high degree of interobserver correlation. ${ }^{3}$ The grades were compared with those assessed in 1077 men (aged 18-69) and 1099 women (aged 18-69) taken from a normal factory population and not receiving any drug. ${ }^{4}$ Statistical analysis for this comparison was by the $\chi^{2}$ method. 